\title{
Frazeodydaktyka i frazeotranslacja jako nowe dyscypliny frazeologii stosowanej
}

Praseodidactics and phraseotranslation: new disciplines in applied phraseology

\author{
Monika SUŁKOWSKA \\ Uniwersytet Śląski w Katowicach/ University of Silesia in Katowice \\ E-mail: monika.sulkowska@us.edu.pl
}

\begin{abstract}
The major task of this paper is the implementation of new emerging phraseological disciplines, such as phraseodidactics and phraseotranslation. The author discusses the attempt to specify and deploy those new disciplines. Taking into account a wide range of phraseological phenomena in all natural languages and the need to implement effective glottodidactis and translation, the development of phraseological didactics and phraseological translation may appear to be useful and of high importance.
\end{abstract}

Keywords : phraseology, phraseodidactics, phraseotranslation.

\section{Wstęp}

Frazeologia jako nauka o utrwalonych strukturach polileksykalnych ma już długą $i$ bogatą historię. Współczesna rzeczywistość pokazuje jednak nowe potrzeby i wyzwania, które stoją przed szeroko pojętą nauką o zasobie frazeologicznym różnych języków. Zagadnienia ta wymagają bardzo często badań interdyscyplinarnych, ponieważ nie można rozwiązać ich w sposób wyczerpujący na gruncie jednej tylko dziedziny badawczej.

Bardzo ważną kwestią we współczesnym świecie jest skuteczna dydaktyka języków obcych oraz ich sprawny, międzyjęzykowy przekład. W obydwu wypadkach rodzą się istotne problemy w zakresie frazeologii. Jest ona zwykle bardzo kłopotliwa w nauczaniu i uczeniu się języków obcych, a także w procesach przekładu. W związku z powyższym zasadne wydaje się powołanie nowych dziedzin interdyscyplinarnych: frazeodydaktyki i frazeotranslacji, które pozwalam sobie postulować w niniejszym tekście.

\section{Cele i problemy frazeodydaktyki}

Frazeodydaktyka, nazywana również dydaktyką frazeologii, jest kształtującą się dopiero dyscypliną z obszaru językoznawstwa stosowanego, która z jednej strony opiera się na wiedzy oraz doświadczeniach językoznawstwa, w tym frazeologii, a z drugiej wykorzystuje badania m.in. z zakresu dydaktyki ogólnej, neurolingwistyki i psycholingwistyki (cf. p.ex. M. Sułkowska 2013a, I. González Rey 2014). 
Termin frazeodydaktyka pojawił się na przełomie XX i XXI w., głównie w pracach niemieckich frazeologów (cf. P. Kühn 1985, 1987, 1992, S. Ettinger 1998, R. Hessky 1992, H.H.Lüger 1997, H.H. Lüger/ M. Lorenz Bourjot 2001). Obecnie frazeodydaktyka rozwija się nadal przede wszystkim za sprawą niemieckich badaczy oraz hiszpańskiego ośrodka naukowego w Santiago de Compostela (cf. S.Ettinger 2011, 2012, 2013, 2014, I. González Rey 2011, 2012, 2014), a także za sprawą skromnego udziału piszącej te słowa (cf. M.Sułkowska 2009a, 2009b, 2010, 2011, 2013a, 2014, 2016).

Głównym celem frazeodydaktyki jest rozwijanie biernych i czynnych kompetencji frazeologicznych w języku ojczystym oraz przede wszystkim w językach obcych, w których ta sfera na ogół powoduje najwięcej trudności. Poniższy schemat przedstawia ramowo główne założenia oraz obszary działania frazeodydaktyki.

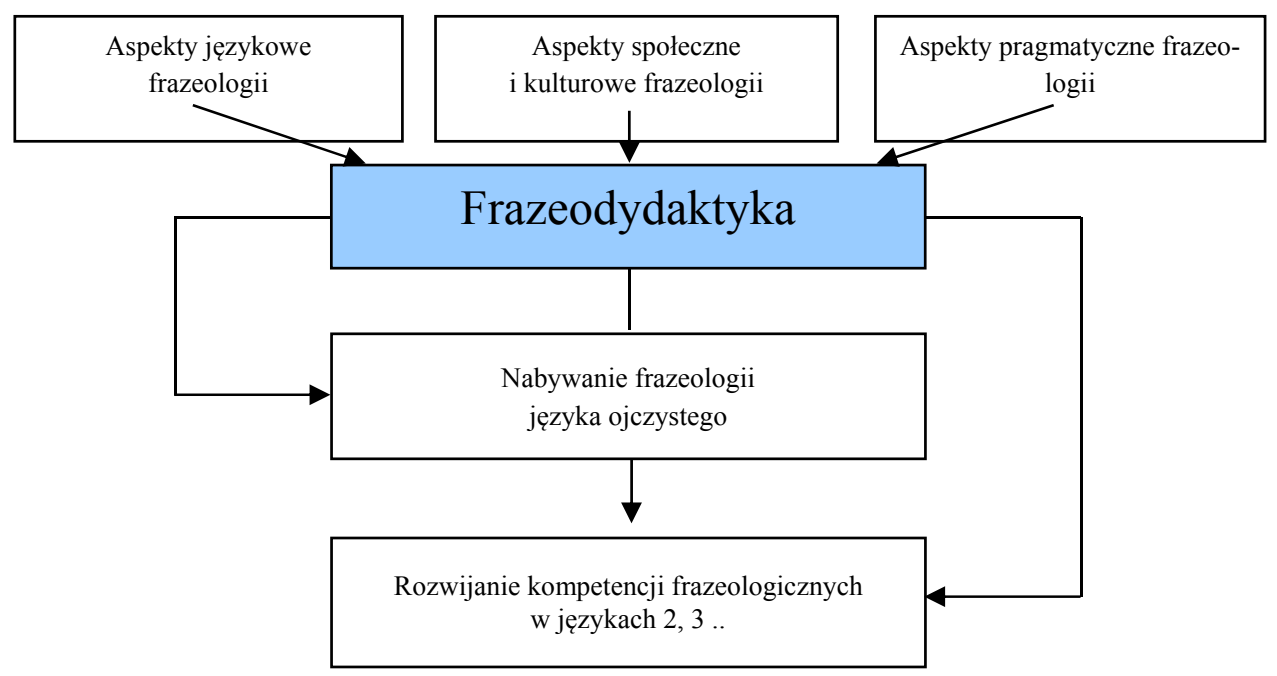

Fig. 1. Cele i obszary działania frazeodydaktyki.

Rozwijanie oraz doskonalenie biernych i czynnych kompetencji frazeologicznych u osób aspirujących do bardzo dobrej znajomości języków obcych jest zadaniem bardzo ważnym i aktualnym we współczesnej glottodydaktyce, ale wbrew tym potrzebom, nie jest to praktyka zbyt popularna. Frazeologia bywa ciągle interpretowana jako pewien naddatek plasujący się ponad podstawowymi kompetencjami językowymi, w związku z czym bywa traktowana dość marginalnie w procesach glottodydaktycznych.

Zakres współczesnej frazeologii znacznie się zwiększył w porównaniu z tym, czym frazeologia zajmowała się na początku swoich badań. Obecnie obejmuje ona swym zasięgiem nie tylko tradycyjne frazeologizmy, idiomy, sentencje czy przysłowia, ale także różnego rodzaju związki i połączenia językowe, które są odtwarzane, a nie tworzone doraźnie przez użytkowników języka w aktach mowy. Są to zatem przeróżne kolokacje, terminy specjalistyczne, wskaźniki frazeologiczne itp. Taka koncepcja frazeologii sprawia, że przedmiot jej badań jest szeroki i obejmuje spory procent wszystkich naszych wypowiedzi. 
W konsekwencji frazeodydaktyka staje się również istotnym obszarem w kształceniu językowym, zwłaszcza że kompetencje frazeologiczne wymagają zintegrowania różnych kompetencji językowych, komunikacyjnych, a także pozalingwistycznych. Ramowo przedstawia to poniższy schemat.

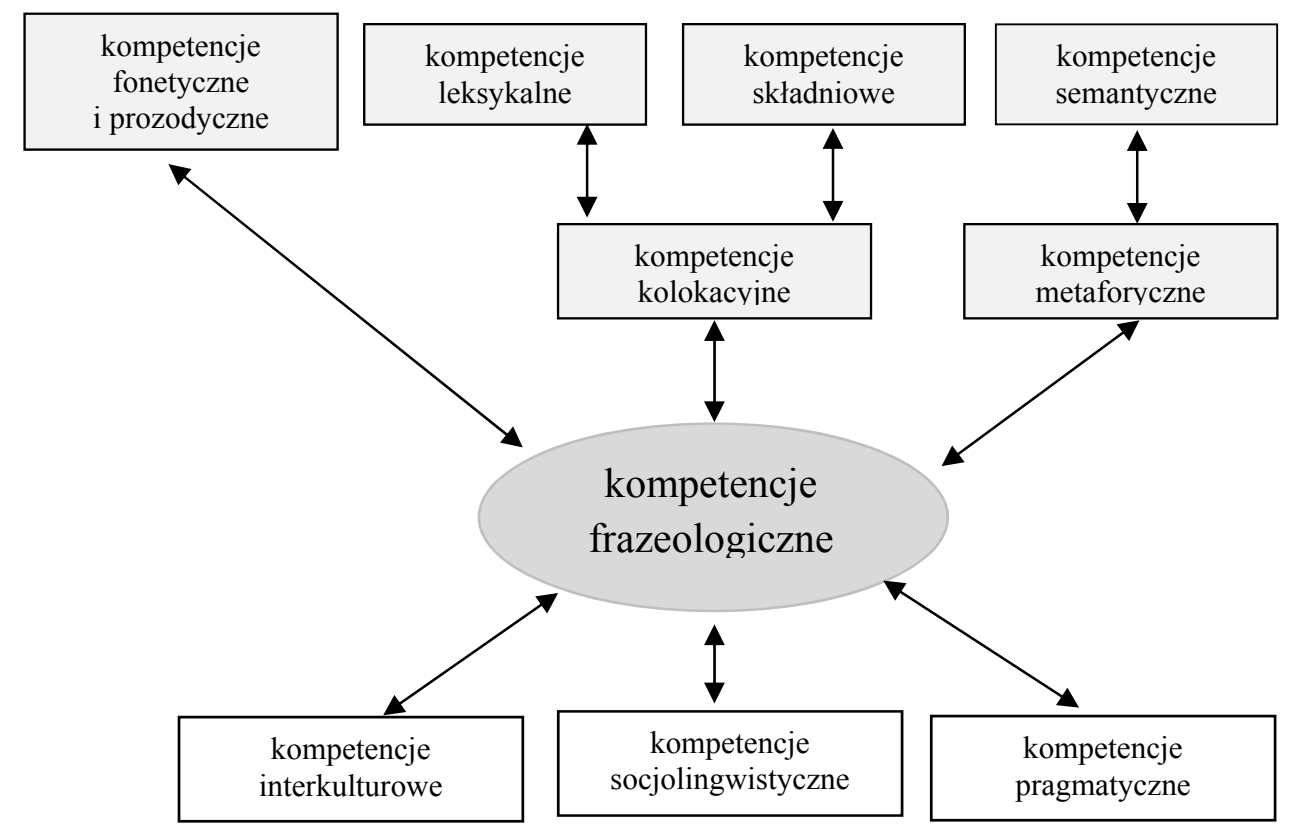

Fig. 2. Korelacja kompetencji frazeologicznych oraz innych kompetencji komunikacyjnych, językowych i pozajęzykowych.

Współczesne koncepcje nauczania i uczenia się języków obcych, ukierunkowane przede wszystkim na kompetencję komunikacyjną i umiejętność porozumiewania się, przypisują dużą rolę nauczaniu słownictwa. Komponent leksykalny z tej perspektywy pozostaje właściwie centralnym elementem języka, dlatego też w ostatnich czasach studia nad słownictwem rozwijają się bardzo intensywnie. Jednostki leksykalne opisywane są z punktu widzenia słowotwórczego, znaczeniowego, a także z punktu widzenia ich kolokacji, czyli możliwości ich występowania z innymi jednostkami leksykalnymi. Zwłaszcza ten ostatni aspekt pozostaje bardzo istotny dla procesu nauczania i uczenia się języka obcego, gdyż wiele błędów w komunikacji w języku wyuczonym wynika z niewłaściwego stosowania reguł kolokacyjnych, a jest to najczęściej efektem przenoszenia tych reguł z języka ojczystego. Stąd też istotna rola przyswajania nie tylko samego leksemu, ale zarazem kontekstów jego użycia, które ilustrują działające w danym przypadku reguły kolokacyjne. W obrębie zasobu leksykalnego każdego języka znaczącą rolę odgrywają utrwalone struktury wielowyrazowe. Jednostki te są zwykle kłopotliwe dla uczących się języka obcego, ponieważ, jak podkreśla to np. G.Gross (1996), użytkownik języka obcego bardzo często nie może zrozumieć ich globalnego sensu, pomimo że rozumie znaczenie wszystkich ich komponentów. W tym zakresie najbardziej problematyczne okazują się struktury o znaczeniach idiomatycznych. 
Problem przyswajania związków idiomatycznych w procesie uczenia się języka obcego badany był np. przez E.Kellermana (1983). Wyniki jego eksperymentów pokazują, że uczący się niechętnie przenoszą idiomy swojego ojczystego języka do języka obcego, uważając je za konstrukcje typowe tylko dla jednego języka i przez to nie nadające się do przenoszenia. Działa tu postulowana przez E. Kellermana (ibidem) reguła psycholingwistycznego nacechowania, która warunkuje przenoszenie konstrukcji języka ojczystego do języka przyswajanego. Konstrukcje psychologicznie nacechowane są odbierane przez uczącego się jako wyjątkowe, nieregularne lub w jakiś sposób niezwykłe, dlatego są postrzegane jako specyficzne dla L1 i w efekcie są niechętnie transponowane do L2. Ich przeciwieństwem są konstrukcje neutralne, które są w konsekwencji często kalkowane w języku obcym. Proces ten nazywany jest transferabilnością. Jest on odwrotnie proporcjonalny do stopnia nacechowania danej konstrukcji. Psycholingwistyczne nacechowanie jest jednak indywidualnie odbierane przez każdego uczącego się, zależy od jego językowego doświadczenia, świadomości i kultury, stąd obserwować można dość istotne różnice w transferabilności dokonywanej przez poszczególne osoby. Pewnym obiektywnym wyznacznikiem może być tutaj postulowane już wcześniej przez L.Selinkera (1969) kryterium częstotliwości: im struktura częstsza w języku ojczystym ucznia, tym większe prawdopodobieństwo przeniesienia jej do przyswajanego języka obcego.

L. Zaręba (2004) pokazuje trudności, które napotyka uczący się w zakresie obcej frazeologii. W syntetycznym ujęciu trudności te są następujące:

- rozbudowana forma zleksykalizowanej struktury wielowyrazowej, która składa się z kilku rozdzielnych elementów;

- nieregularności w zakresie składni i ciągłości leksykalnej;

- częsty brak motywacji pozajęzykowej;

- $\quad$ konieczność zapamiętania rozbudowanego signifiant o bardzo arbitralnym signifié.

Według Europejskiego Systemu Opisu Kształcenia Językowego, pewne podstawowe, utrwalone struktury powinny pojawiać się już na poziomie A, zwłaszcza A2 (według europejskiej skali biegłości językowej). Natomiast pełne i świadome używanie związków idiomatycznych oraz przysłów charakteryzuje poziom C. Oznacza to zatem potrzebę wprowadzania najprostszych struktur frazeologicznych już na początku procesu przyswajania języka obcego. Potrzeba ta jednak wyraźnie wzrasta na poziomie zaawansowanym, na którym kształcenie $\mathrm{w}$ zakresie frazeologii powinno być już ukierunkowane i bardziej świadome.

Ukierunkowane nauczanie frazeologii nie ma jednak w europejskich programach kształcenia zbyt bogatej tradycji. Poza tym nie naucza się właściwie frazeologii ojczystej. Wyjątek stanowią tutaj niektóre kierunki filologiczne studiów wyższych w Rosji, gdzie frazeologia ojczysta bywa nauczana jako odrębna dziedzina. Podobne praktyki obserwuje się też np. we Francji, na Uniwersytecie Rennes 2, gdzie w programie studiów jest kurs frazeologii, oraz w Hiszpanii, gdzie takie kursy bywają przewidziane dla doktorantów, a więc w kształceniu trzeciego cyklu (cf. I. González Rey 2007).

Niemniej jednak, studia wyższe filologiczne, zwłaszcza filologie obce, zazwyczaj 
nie przewidują w swoich programach odrębnych kursów poświęconych frazeologii, zarówno praktycznej, jak i teoretycznej. Przyswajanie zasobu frazeologicznego przez przyszłych specjalistów z danego języka odbywa się zwykle w sposób mało świadomy na zajęciach z praktycznej nauki języka kierunkowego. Wiedza teoretyczna z zakresu frazeologii bywa zaś przekazywana w różnym stopniu, nierzadko dość cząstkowym, na zajęciach oraz seminariach specjalizacyjnych $\mathrm{z}$ językoznawstwa. Wszystko to sprawia, iż niestety dość często absolwenci neofilologii, a więc przyszli nauczyciele języków obcych bądź tłumacze, nie mają zbyt dużej wiedzy teoretycznej ani też dużych umiejętności praktycznych $\mathrm{w}$ dziedzinie frazeologii.

Problem przyswajania frazeologii oraz jej nauczania sprowadza się także do problemu odpowiednich materiałów niezbędnych w tym procesie. Na rynku dostępne są różnego typu słowniki frazeologiczne, ale już np. opracowania z ćwiczeniami frazeologicznymi należą do rzadkości. Być może skąpa oferta dydaktyczna wynika z faktu, iż ciągle brakuje opracowań frekwencyjnych dotyczących frazeologii. Listy frekwencyjne grupujące związki różnych typów pod względem częstości ich użycia w różnych językach są narzędziem wręcz koniecznym przy opracowywaniu rzetelnych materiałów dydaktycznych z zakresu frazeologii.

\section{Założenia i problematyka badawcza frazeotranslacji}

Frazeotranslacja, postulowana w niniejszym tekście, nie ma jeszcze podwalin teoretycznych ani wydzielonej tradycji. Ale są przesłanki, aby mogła stać się nową, zintegrowaną dyscypliną badawczą. (Cf. M.Sułkowska: 2009c, 2013a,b, 2016, 2017). Praktycy i teoretycy przekładu wiedzą doskonale, że utrwalone w językach naturalnych struktury wielowyrazowe stanowią poważne wyzwanie w procesach przekładu i bywają znaczną trudnością nawet dla zawodowych tłumaczy.

Postulowana frazeotranslacja ma charakter interdyscyplinarny. Łączy frazeologię, współcześnie rozumianą szeroko, $\mathrm{z}$ translatoryką jako nauką o różnych typach przekładu międzyjęzykowego. Frazeotranslacja wykorzystuje zdobycze językoznawstwa kontrastywnego oraz językoznawstwa stosowanego, w tym przede wszystkim wspomnianej już frazeodydaktyki. Integrację i korelację różnych dyscyplin naukowych w obrębie frazeotranslacji przedstawia poniższy schemat.

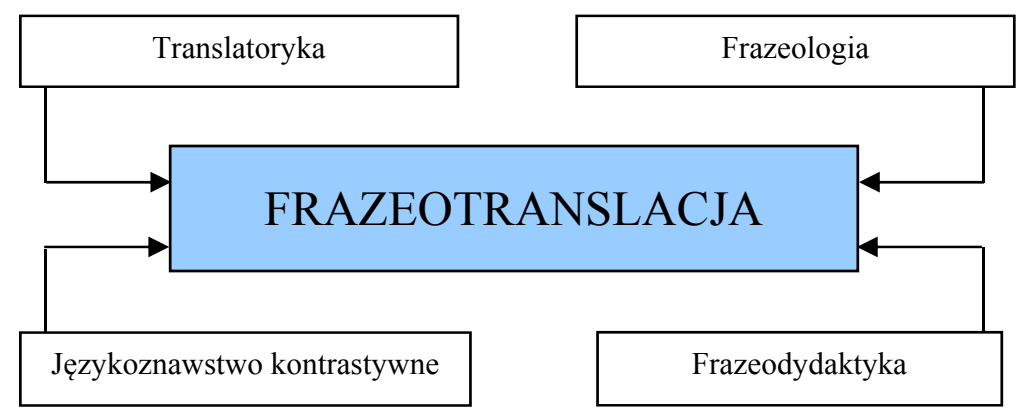

Fig. 3. Integracja i korelacja różnych dyscyplin naukowych w obrębie frazeotranslacji. 
Językoznawstwo kontrastywne i jego zdobycze naukowe były i są od dawna wykorzystywane we frazeologii porównawczej. Analizy porównawcze konwencjonalnie rozumianych związków frazeologicznych w różnych językach mają już długą i bogatą tradycję, a w ostatnich latach zwiększone zainteresowanie w tym zakresie wzbudzają np. kolokacje lub wielowyrazowe terminy specjalistyczne (cf. np. S.Bąba 1998, 2003, 2008, W. Mieder 2009). Różnorodne badania potwierdzają, że struktury frazeologiczne są grupą bardzo zróżnicowaną, a ich międzyjęzykowa ekwiwalencja ma charakter skalarny. Część struktur ma dobre ekwiwalenty w innych językach naturalnych. Są jednak i takie struktury, które nie mają bezpośrednich odpowiedników w innych językach i w konsekwencji są to elementy bardzo trudno przekładalne.

Biorąc pod uwagę gradualność ekwiwalencji, należy także wymienić grupę pośrednią, w praktyce najliczniejszą. W tej grupie odnajdujemy struktury, które właściwie mają swoje odpowiedniki w innym języku naturalnym, ale nie są to odpowiedniki całkowicie ekwiwalentne w każdym wymiarze.

W perspektywie kontrastywnej można zatem mówić o trzech zasadniczych grupach struktur frazeologicznych. Są to (cf. M. Sułkowska 2003):

- ekwiwalenty całkowite (homologi) - związki o podobnej budowie leksykalno-gramatycznej oraz tożsamym obrazowaniu w różnych językach. Np. avoir les mains liées (fr.) i mieć zwiąane ręce (pol.);

- $\quad$ odpowiedniki częściowe - związki różniące się pod względem obrazowania oraz struktury leksykalno-gramatycznej, ale zachowujące frazeologicznoidiomatyczny charakter w obydwu traktowanych językach. Np. lever le pied (fr.), dać nogę (pol.);

- $\quad$ idiomy - związki charakterystyczne tylko dla jednego $\mathrm{z}$ analizowanych języków. Nie mają one adekwatnych odpowiedników w drugim języku. W konsekwencji ich przekład nigdy nie jest bezpośredni i zwykle wymaga zastosowania specyficznych strategii translacyjnych. Np. avoir un cheveu sur la langue - idiom francuski, poszło mu w pięty - idiom polski.

Podział struktur frazeologicznych wraz z przyporządkowanymi im typami ekwiwalencji międzyjęzykowej przedstawia poniższy schemat.
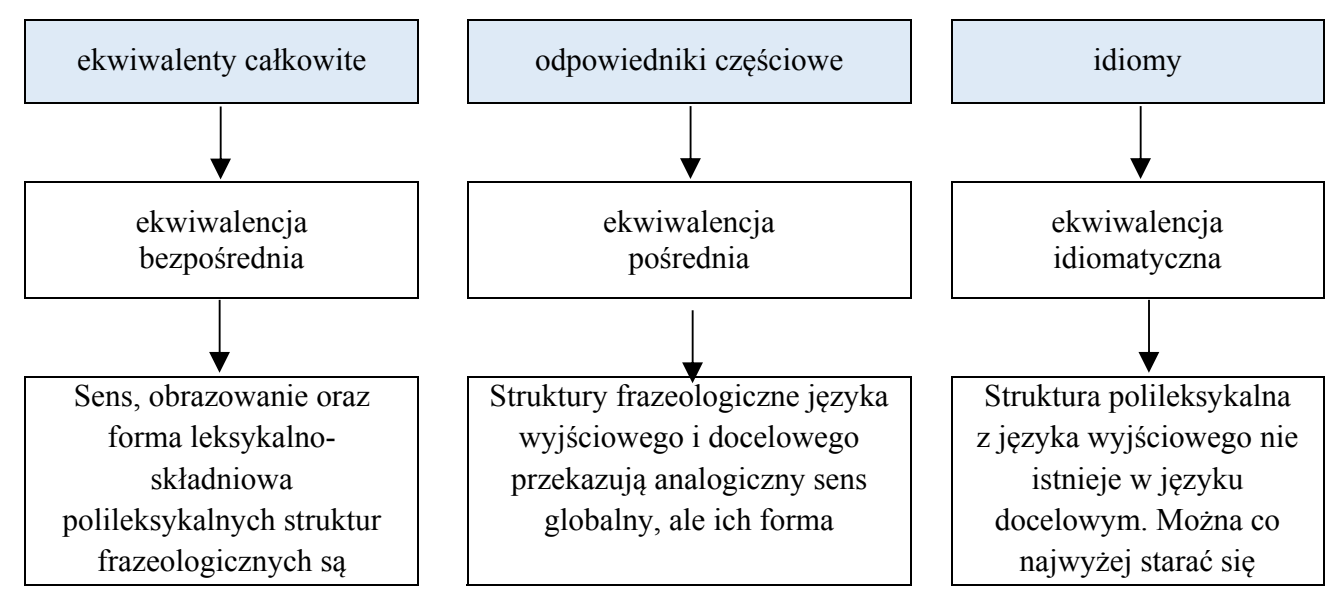


\begin{tabular}{|c|c|c|}
\hline $\begin{array}{c}\text { anlogiczne w językach } \\
\text { wyjściowym i docelowym. }\end{array}$ & $\begin{array}{c}\text { leksykalno-składniowa oraz } \\
\text { obrazowanie są różne. }\end{array}$ & $\begin{array}{c}\text { przekazać jej sens za } \\
\text { pomocą innych środków } \\
\text { językowych. }\end{array}$ \\
\hline
\end{tabular}

Fig. 4: Podziat struktur frazeologicznych wraz z przyporzadkowanymi im typami międzyjęzykowej ekwiwalencji.

W przekładoznawstwie (cf. H. Lebiedziński 1981) można mówić o dwóch podstawowych metodach thumaczenia. Są to: (a) metoda lingwistyczna - oparta na relacji pomiędzy strukturami językowymi w L1 i L2, (b) metoda odwołująca się do treści która wykorzystuje referencję pozajęzykową.

Ich funkcjonowanie wizualnie przedstawia poniższy schemat. Metoda lingwistyczna:

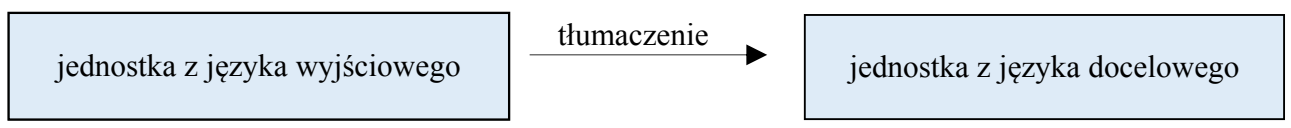

Metoda odwołująca się do treści:

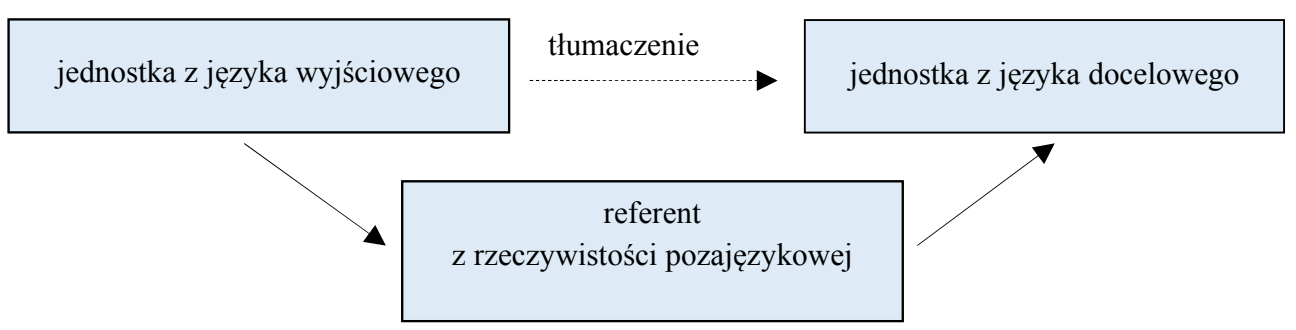

Fig. 5: Podstawowy podzial metod tlumaczenia.

Jeżeli chodzi o thumaczenie struktur frazeologicznych, to metoda lingwistyczna jest możliwa do zastosowania co najwyżej w przypadku ekwiwalentów całkowitych. Natomiast we wszystkich pozostałych przypadkach należy posługiwać się metodą odwołującą się do treści.

Tłumaczenie frazeologii jest dotychczas bardzo rzadko traktowane oddzielnie na gruncie translatoryki, choć obserwacja pracy tłumaczy pokazuje, że w praktyce miewają oni w tym zakresie spore trudności.

C.M. Xatara (2002) twierdzi, że tłumaczenie literalne we frazeologii jest możliwe wtedy, gdy frazeologizm z języka wyjściowego konceptualizuje się w identyczną strukturę w języku docelowym. Mamy wtedy do czynienia z sytuacją, w której zachowane zostają te same elementy leksykalne oraz taka sama struktura gramatyczna i składniowa, a także wywołany zostaje ten sam efekt komunikacyjny i ekspresywny. Niemniej jednak na gruncie frazeologii zdecydowanie częstsze jest thumaczenie nieliteralne, konieczne np. w przypadku struktur idiomatycznych lub związków, które nie mają bezpośrednich ekwiwalentów w innym języku. W tej sytuacji można wyróżnić trzy możliwe przypadki: 
- $\quad$ Frazeologizm z języka wyjściowego thumaczy się za pomocą podobnego lecz nie identycznego frazeologizmu w języku docelowym.

- Frazeologizm z języka wyjściowego tłumaczy się za pomocą całkiem innej struktury wyrazowej.

- Frazeologizm z języka wyjściowego tłumaczy się za pomocą parafrazy. M. Moldoveanu (2001) wskazuje trzy różne możliwości transferu międzyjęzykowego struktur metaforycznych wykorzystywanych we frazeologii. Są one następujące:

- $\quad$ Ekwiwalent w języku docelowym jest luźnym połączeniem wyrazowym; w konsekwencji metafora z języka wyjściowego zanika.

- Ekwiwalent w języku docelowym zawiera metaforę zleksykalizowaną pochodzącą z tej samej domeny semantycznej co w języku wyjściowym; jest to sytuacja dość częsta w przekładzie języków europejskich lub dość bliskich pod względem socjokulturowym.

- Ekwiwalent zawiera metaforę zleksykalizowaną, ale domeny semantyczne w języku wyjściowym i docelowym są różne.

Transfer międzyjęzykowy frazeologizmów bazujących na metaforze implikuje konieczność stosowania różnych zabiegów językowych, takich jak np. różne reorganizacje gramatyczne i składniowe, interwencje na poziomie stylistycznym, a nawet modyfikacje semantyczne i pragmatyczne.

We frazeologii obserwuje się gradację skali skostnienia i utrwalenia językowego: $\mathrm{z}$ jednej strony tej skali sytuują się struktury o najwyższym poziomie sfrazeologizowania, a oddalając się sukcesywnie od tego bieguna, dochodzimy do struktur o coraz to mniejszym stopniu nieregularności i utrwalenia. Zależność tę dobrze ilustruje poniższy schemat.

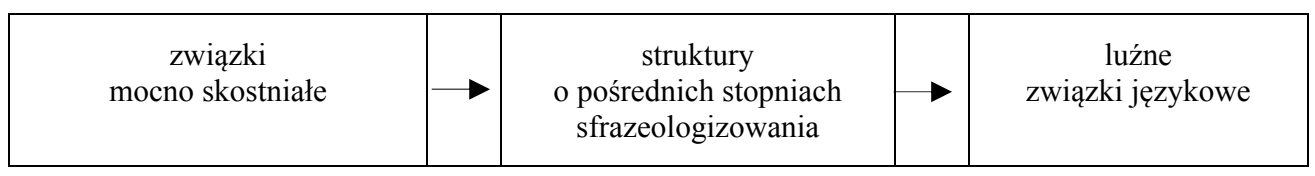

Fig. 6. Gradualny charakter frazeologii.

Wbrew oczekiwaniom całkowite sfrazeologizowanie nie stanowi aż tak dużego problemu w przekładzie. W tym wypadku należy jedynie znać określoną grupę ekwiwalentów i traktować wielowyrazowe struktury właściwie podobnie do pojedynczych leksemów. Natomiast tłumaczenie struktur o pośrednich stopniach sfrazeologizowania, takich jak np. różnego typu utrwalone kolokacje czy polileksykalne terminy specjalistyczne, jest już zadaniem znacznie trudniejszym, zwłaszcza że dochodzi tu jeszcze kwestia właściwego rozpoznania i wydzielenia takiej struktury w języku wyjściowym.

Odpowiedzialność thumaczy we frazeologii jest bardzo duża: po pierwsze muszą oni poprawnie odkodować sfrazeologizowane struktury w języku wyjściowym, a po drugie, muszą dokonać ich właściwego transferu do języka docelowego. Sprawni tłumacze powinni radzić sobie z rozległymi problemami frazeologii, wśród których wymienić należy przede wszystkim: 
- $\quad$ poprawne rozpoznanie utrwalonej struktury wielowyrazowej w języku wyjściowym ;

- $\quad$ właściwe odkodowanie sensu takiej struktury i jej ewentualnych konotacji kulturowych oraz pragmatycznych ;

- $\quad$ wybór i zastosowanie odpowiedniej w danym wypadku strategii frazeotranslacyjnej ;

- dobór właściwego ekwiwalentu w języku docelowym.

Rozległe zadania tłumaczy na gruncie frazeologii, a także obserwacja problemów, jakie napotykają oni w praktyce bez wątpienia uzasadniają konieczność ukonstytuowania i rozwoju frazeotranslacji jako ważnej dziedziny w obrębie ogólnej, interdyscyplinarnie rozumianej translatoryki.

Każdy przekład międzyjęzykowy stwarza ciągłe i regularne problemy z powodu różnic w kategoryzacji i gramatyczności języków, ale trudności te jeszcze się pomnażają w thumaczeniu szeroko pojętej frazeologii. W tym przypadku dochodzi jeszcze wymiar idiomatyczny, procesy tropiczne, synteza oraz globalizacja semantyczna i składniowa, które nie są ani regularne, ani ewidentne w różnych kodach językowych.

\section{Frazeodydaktyka i frazeotranslacja jako wyzwania współczesnej frazeologii stosowanej}

Trudno wyobrazić sobie skuteczną frazeotranslację bez poprzedzającej ją, efektywnej frazeodydaktyki. W takiej perspektywie obydwie dyscypliny są komplementarne. Obydwie stanowią też zintegrowane dziedziny badawcze użyteczne dla zaawansowanej glottodydaktyki oraz specjalistycznej translatoryki. J.-P. Colson $(1992,1995)$ z Instytutu Marie Haps w Brukseli, zajmującego się kształceniem tłumaczy ze specjalnym zwróceniem uwagi na frazeologię, proponuje kilka ścieżek dydaktycznych możliwych do stosowania $\mathrm{w}$ dydaktyce frazeotranslacji. Proponowana strategia frazeodydaktyczna składa się z następujących etapów:

Wyodrębnienie frazeologizmów. Jest to pierwszy etap, który ma na celu uwrażliwienie na frazeologię. Uczący się mają za zadanie zaznaczenie w tekście do thumaczenia wszystkich struktur charakterystycznych dla tego języka, co powoduje zwrócenie ich szczególnej uwagi na ewentualne utrwalone i nieregularne związki wyrazowe lub użycia idiomatyczne.

Analiza semantyczna. W następnym etapie działań, wydzielone frazeologizmy stają się przedmiotem analizy z punktu widzenia ich znaczenia. Ten etap może być wzbogacony przez różnego rodzaju ćwiczenia z zakresu synonimów, antonimów i pól semantycznych.

Analiza kontekstowa i makrostrukturalna. W trzecim etapie przyszły tłumacz powinien dokonać analizy frazeologizmów w kontekście językowym i pozajęzykowym. Ten etap jest bardzo ważny zwłaszcza w przypadku związków idiomatycznych.

Podejście teoretyczno-modularne. Jest również rzeczą istotną, aby wzbogacić proces rozwijania kompetencji frazeologicznych poprzez tzw. podejście modularne. Przyszły thumacz powinien np. gromadzić sobie własny indeks struktur pogrupowanych tematycznie. Kolokacje i wyrażenia idiomatyczne powinny zajmować w nim miejsce szczególne, a ich użycia powinny być ilustrowane przykładami. 
Ciekawe ćwiczenie frazeodydaktyczne, użyteczne w procesie kształcenia frazeotranslacji, proponuje także S.Mejri (2011). Wprowadza on pojęcie pokrycia frazeologicznego (couverture phraséologique), które odnosi przede wszystkim do frazeologii tekstów specjalistycznych. Pokrycie frazeologiczne tekstu to stosunek sfrazeologizowanych struktur i kolokacji do ogólnej liczby leksemów w tym tekście. Koncepcja pokrycia frazeologicznego wydaje się interesująca z punktu widzenia dydaktyki frazeotranslacji, ponieważ można ją wykorzystać w ćwiczeniach polegających na porównywaniu pokrycia frazeologicznego tekstów w języku wyjściowym i docelowym.

Można podzielić ogólne pokrycie frazeologiczne na podtypy uwzględniające np. tylko kolokacje, terminy specjalistyczne, czy idiomy. Analizy kontrastywne bazujące na koncepcji pokrycia frazeologicznego, choć z pozoru dość banalne, mogą uwrażliwiać przyszłych tłumaczy na kwestię frazeotranslacji, a także być okazją do obserwacji funkacjonowania frazeologii w różnych kodach językowych. Uczący się mogą zaobserwować bezpośrednio zmiany w tekstach będące konsekwencją przekładu sfery frazeologicznej, a także nabyć nawyk wykorzystywania struktur frazeologicznych w swoich własnych przekładach.

W dydaktyce frazeologicznej J.-P. Colson $(1992,1995)$ zwraca także uwagę na bardzo istotną rolę szeroko pojętego kontekstu, który ważny jest w przyszłej pracy thumacza, natomiast L. Wéry (2000) podkreśla zalety dokumentów autentycznych. Dokumenty autentyczne, zwłaszcza te pochodzące ze środków masowego przekazu, jak np. tytuły prasowe, fragmenty filmów, slogany reklamowe, mogą być bardzo dobrym źródłem struktur frazeologicznych, a ich wprowadzenie do procesów kształcenia językowego może być bardzo użyteczne, również jeśli chodzi o rozwijanie produktywnych kompetencji frazeologicznych, tak ważnych u thumaczy języków.

Nabywanie kompetencji frazeologicznych w języku obcym, zwłaszcza tych na poziomie produkcji, to proces względnie powolny, który wymaga sporo wysiłku i zaangażowania, zarówno ze strony uczącego się, jak i jego nauczyciela. Nabycie tych kompetencji jest jednak niezbędne w przypadku aspirowania do pełnej znajomości języka obcego, a taka wymagana jest bez wątpienia u różnego typu thumaczy.

Współczesna frazeologia stosowana ma zatem przed sobą spore, nowe wyzwania. Może im sprostać, korzystając z niewątpliwych, dotychczasowych zdobyczy frazeologii ogólnej i porównawczej, a także otwierając się na inne dziedziny nauk, których wiedza może wspomóc nowe badania. Frazeodydaktyka i frazeotranslacja rozumiane w ten sposób mają zatem szanse na rozwój i obiecujące wyniki badań.

\section{Bibliografia}

Bąba, S. (1998), Materiaty do bibliografii frazeologii polskiej (prace opublikowane w latach 1945-95), t. 1. Poznań.

Bąba, S. (2003), Materiaty do bibliografii frazeologii polskiej (prace opublikowane w latach 1996-2000 oraz uzupetnienia za lata 1983-2000), t. 2. Poznań.

Bąba, S. (2008), Materiaty do bibliografii frazeologii polskiej (prace opublikowane w latach 2001-2005), t. 3. Poznań. 
Colson, J.-P. (1992), Ébauche d'une didactique des expressions idiomatiques en langue étrangère. (w:) Terminologie et Traduction 2/3, 165-181.

Colson, J.-P. (1995), Quelques remarques sur l'enseignement de la phraséologie aux futurs traducteurs et interprètes, (w:) Le Langage et l'Homme XXX, 2-3, 147156.

Ettinger, S. (1998), Einige Überlegungen zur Phrasodidaktik, (w:) W. Eismann (red.), Europhras 95: Europäische Phraseologie im Vergleich: Gemeinsames Erbe und kulturelle Vielfalt. Bochum, 201-217.

Ettinger, S. (2011), Einige kritische Fragen zum gegenwärtigen Forschungsstand der Phraseodidaktik, (w:) P. Schäfer/ Ch. Schowalter (red.), In mediam linguam. Mediensprache-Redewendungen-Sprachvermittlung. Festschrift für Heinz-Helmut Lüger. Landau, 231-250.

Ettinger, S. (2012), Einige phraseodidaktische Überlegungen zur Frequenz, zur Disponibilität und zur Bekanntheit französischer Idiome und Sprichwörter, (w:) Szavak, frazémák szótárak/ Mots, phrasèmes, dictionnaires - Írások Bárdosi Vilmos 60. születésnapjára/ Mélanges offerts à Vilmos Bárdosi pour ses 60 ans. $R e$ vue d'Études Françaises, numéro spécial, Budapest, 85-104.

Ettinger, S. (2013), Aktiver Phrasemgebrauch und/oder passive Phrassemkenntinisse im Fremdsprachenunterricht. Einige phraseodidaktische Überlegungen, (w:) I. González Rey (red.), Phraseodidactic Studies on German as a Foreign Language. Phraseodidaktische Studien zu Deutsch als Fremdsprache. Hamburg. Date of access: 01.12.2015, 11-30. http://www.verlagdrkovac.de/978-3-8300-6558-6.htm bzw. Stefan Ettinger.

Ettinger, S. (2014), Le problème de l'emploi actif et/ou de connaissances passives des phrasèmes chez les apprenants de langues étrangères, (w:) I. González Rey (red.), Outils et méthodes d'apprentissage en phraséodidactique. Fernelmont, 17-38.

González Rey, I. (2007), La didactique du français idiomatique. Fernelmont.

González Rey, I. (2011), La phraséodidactique du français, un siècle de vie: de Charles Bally à aujourd'hui, (w:) A. Pamies et. al. (red.), Multi-Lingual Phraseography: Second Language Learning and Translation Applications. Baltmannsweiler, 225-234.

González Rey, I. (2012), De la didáctica de la fraseología a la fraseodidáctica, (w:) Paremia 21, 67-84.

González Rey, I. (red.) (2014), Outils et méthodes d'apprentissage en phraséodidactique. Fernelmont.

Gross, G. (1996), Les expressions figées en français. Noms composés et autres locutions. Paris.

Hessky, R. (1992), Aspekte der Verwendung von Phraseologismen im Unterrich Deutsch als Fremdsprache, (w:) Fremdsprachen Lehren und Lernen 21, 159-168.

Kellerman, E. (1983), Now you see it, now you don't, (w:) Language transfer in language learning, red. S. Gass/ L.Selinker, Rowley, Mass.

Kühn, P. (1985), Phraseologismen und ihr semantischer Mehrwert. Jemandem auf die Finger gucken in einer Bundestagsrede, (w:) Sprache und Literatur in Wissenschaft und Unterricht 16, 37-46. 
Kühn, P. (1987), Deutsch als Fremdsprache im phraseodidaktischen Dornröschenschlaf. Vorschläge für eine Neukonzeption phraseodidaktischer Hilfsmittel, (w:) Framdsprachen Lehren und Lernen 16, 62-79.

Kühn, P. (1992), Phraseodidaktik. Entwicklungen. Probleme und Überlegungen für den Muttersprachenunter- richtund den Unterricht DaF, (w:) Framdsprachen Lehren und Lernen 21, 169-189.

Lebiedziński, H. (1981), Elementy przekładoznawstwa ogólnego. Warszawa.

Lüger, H.-H. (1997), Anregungen zur Phraseodidaktik, (w:) Beiträge zur Fremdsprachenvermittlung 32, 69-120.

Lüger, H.-H./ M. Lorenz Bourjot (2001), Phraseologie und Phraseodidaktik, (w:) Französisch heute 4, 200, 462-464.

Mejri, S. (2011), Phraséologie et traduction des textes spécialisés, Alicante: Universidad de Alicante. 125-137. Date of access: 20.10.2011, http://192.168.170.5/pmb/catalog.php

Mieder, W. (2009), International Bibliography of Paremiology and Phraseology, vol. 1, 2. Berlin/ New York.

Moldoveanu, M. (2001), Structures métaphoriques dans la phraséologie: quels enjeux pour la traduction? (w:) L'éloge de la différence: la voix de l'autre, red. A. Clas/ H. Awaiss/ J. Hardane, Série: Actualité Scientifique, 491-495.

Selinker, L. (1969), Language transfer, (w:) General Linguistics 9/2, 67-92.

Sułkowska, M. (2003), Séquences figées. Étude lexicographique et contrastive. Question d'équivalence. Katowice.

Sułkowska, M. (2009a), Quelques aspects de la phraséodidactique, c'est-à-dire sur l'enseignement-apprentissage des expressions figées en langue étrangère, (w:) Neophilologica 21, 102-114.

Sułkowska, M. (2009b), Z zagadnień frazeodydaktyki, czyli o kształceniu przyszłych nauczycieli języków obcych w zakresie związków frazeologicznych, (w:) M. Pawlak/ A. Mystkowska-Wiertelak/ A. Pietrzykowska (red.), Nauczyciel języków obcych dziś i jutro. Poznań/ Kalisz, 237-247.

Sułkowska, M. (2009c), Przekład jednostek frazeologicznych, (w:) K. Hejwowski/ A. Szczęsny/ U. Topczewska (red.), 50 lat polskiej translatoryki. Warszawa, 401407.

Sułkowska, M. (2010), Typowość i struktury prototypowe we frazeologii oraz ich znaczenie dla frazeodydaktyki, (w:) Poradnik Językowy 6, 48-61.

Sułkowska, M. (2011), Outils, techniques et stratégies servant à développer les compétences phraséologiques, (w:) Linguistica Silesiana 32, 229-246.

Sułkowska, M. (2013a), De la phraséologie à la phraséodidactique. Études théoriques et pratique, Katowice.

Sułkowska, M. (2013b), Kształcenie tlumaczy w zakresie frazeotranslacji, (w:) Rocznik Przekładoznawczy 8, 227-237.

Sułkowska, M. (2014), Dydaktyka frazeologii - sukces czy porażka? (w:) J. SujeckaZając/ A. Jaroszewska/K. Szymankiewicz/ J. Sobańska-Jędrych (red.), Inspiracja. Motywacja. Sukces. Rola materiałów dydaktycznych i form pracy na lekcji języka obcego. Warszawa, 295-312. 
Sułkowska, M. (2016), Phraséodidactique et phraséotraduction: quelques remarques sur les nouvelles disciplines de la phraséologie appliquée, (w:) Yearbook of Phraseology 7, 35-54.

Sułkowska, M. (2017), Frazeotranslacja oraz jej znaczenie w ksztatceniu i doskonaleniu tlumaczy, (w:) Rocznik Przekładoznawczy 12, 341-353.

Wéry, L. (2000), Approche des expressions idiomatiques en FLE, (w:) Le Langage et l'Homme XXXV, 4, 215-232.

Xatara, C.-M. (2002), La traduction phraséologique, (w:) Meta: journal des traducteurs $47,3,441-444$.

Zaręba, L. (2004), Les locutions idiomatiques en philologie romane. Une approche didactique, (w:) L. Zaręba (red.), Szkice z frazeologii porównawczej francuskopolskiej i polsko-francuskiej. Esquisses de phraséologie comparative franco-polonaise et polono-française. Kraków, 159-169. 